\title{
ANALISIS KINERJA ANGGARAN PENDAPATAN BELANJA DAERAH KABUPATEN MOROWALI PADA PERIODE TAHUN 2011-2015
}

\author{
Media Gramini \\ Muh. Yunus Kasim \\ Cici Rianty K. Bidin \\ Jurusna Manajemen, Fakultas Ekonomi, Universitas Tadulako \\ Email: media.gramini21@gmail.com
}

\begin{abstract}
This study aims to determine the performance of local revenue and expenditure budget of Morowali District in the period of 2011-2015. This research is quantitative descriptive. This study uses: (1) analysis performance of the local revenue consisting of variance revenue analysis, regional financial ratio analysis, (2) analysis of local expenditure performance includes: variance analysis of local expenditure, analysis of local expenditure activity, and analysis of local expenditure efficiency. The analysis shows that the performance of Morowali District's local revenue and expenditure budget is poor due to: (1) variance revenue analysis is rated poorly because it has a negative difference; (2) analysis of local financial ratio shows that: (a) the degree of decentralization is very low, $(b)$ independence ratio is very low with a pattern of instructive relationships, (c) dependence ratio has a high level of dependency and (d) effectiveness ratio is considered ineffective. Meanwhile the analysis of the performance of local expenditure shows: (1) variance expenditure analysis is considered good because it has a positive difference (2) activity ratio of expenditure is rated good while capital expenditure is considered less fit because Morowali District prioritizes its budget for operational expenditure than capital expenditures (3) efficiency analysis of expenditure is rated efficient.
\end{abstract}

Keywords: performance budgets, local revenue performance, expenditure performance

\section{ABSTRAK}

Penelitian ini bertujuan untuk mengetahui kinerja anggaran pendapatan belanja daerah Kabupaten Morowali pada periode tahun 2011-2015. Metode yang digunakan adalah metode deskriptif kuantitatif. Penelitian ini menggunakan alat analisis (1) analisis kinerja pendapatan daerah yang terdiri dari Analisis Varians Pendapatan, Analisis Rasio Keuangan Daerah, (2) analisis kinerja belanja daerah terdiri dari Analisis Varians Belanja Daerah, Analisis Keserasian Belanja Daerah, dan Analisis Efisiensi Belanja Daerah. Hasil analisis menunjukkan bahwa Kinerja APBD Kabupaten Morowali dilihat dari analisis kinerja pendapatan daerah Kabupaten Morowali memiliki kinerja kurang baik hal ini ditunjukkan (1) Analisis Varians Pendapatan dinilai kurang baik karena memiliki selisih negatif. (2) Analisis Rasio Keuangan Daerah terdiri dari (a) Derajat desentralisasi dinilai masih sangat rendah, (b)Rasio Kemandirian dinilai masih sangat rendah dengan pola hubungan instruktif, (c) Rasio Ketergantungan dinilai memiliki tingkat ketergantungan yang tinggi dan (d)Rasio Efektivitas PAD dapat dikategorikan tidak efektif. Sedangkan jika dilihat dari analisis kinerja belanja daerah: (1) Analisis Varians Belanja dinilai baik karena memiliki selisih positif (2) Rasio Keserasian belanja operasi dinilai serasi sedangkan belanja modal dinilai kurang serasi, dimana Kabupaten Morowali lebih memprioritaskan anggaran belanjanya untuk belanja operasi dibandingkan dengan belanja modal (3) Analisis Efisiensi Belanja dinilai efisien

Kata Kunci: Kinerja APBD, Kinerja Pendapatan Daerah dan Kinerja Belanja Daerah

\section{PENDAHULUAN}

Penerapan asas desentralisasi merupakan salah satu upaya pemerintah dalam meningkatkan kemajuan pembangunan ekonomi dengan tujuan untuk menghindari terjadinya ketimpangan antara Pemerintah Pusat dan Daerah. Desentralisasi bermakna sebagai kepemilikan kekuasaan untuk menentukan nasib sendiri dan mengelolanya untuk mencapai tujuan yang telah disepakati bersama (Bastian, 2006:331). Dalam UU No. 32 Tahun 2004 menyebutkan bahwa Desentralisasi adalah penyerahan wewenang pemerintahan oleh Pemerintah Pusat kepada daerah otonom untuk mengatur dan mengurus urusan pemerintahan dalam sistem NKRI. Pemerintah daerah memiliki wewenang 


\section{Gramini M.}

dalam menyelenggarakan pemerintahan berdasarkan pada prinsip-prinsip keterbukaan, partisispasi masyarakat, dan pertanggungjawaban kepada masyarakat dengan tujuan untuk menciptakan good governance. Oleh karena itu, pengukuran kinerja pengelolaan keuangan daerah merupakan salah satu hal penting dilakukan untuk menilai tercapainya suatu tujuan dan sasaran secara ekonomi, efisien dan efektif dalam mencapai tujuan, visi dan misi organisasi (Bastian, 2006:274).

Menurut Mahmudi (2010:135) Analisis Kinerja Keuangan tidak hanya menilai dari sisi Pendapatan Daerah saja, tetapi dari sisi Belanja Daerah juga diperlukan. Analisis Kinerja Pendapatan Daerah yang dimaksudkan adalah Analisis Varians Pendapatan Daerah, dan Analisis Rasio Keuangan Daerah. Sedangkan Analisis Kinerja Belanja Daerah terdiri dari Analisis Varians Belanja Daerah, dan Analisis Keserasian Belanja Daerah serta Analisis Efisiensi Belanja Daerah.

Morowali merupakan salah satu kabupaten di wilayah Sulawesi Tengah yang kaya akan sumber daya alam dengan harapan hal tersebut dapat memberikan kontribusi dalam komponen Pendapatan Daerah, sehingga akan berpengaruh pada realisasi APBD. Berkaitan dengan hal tersebut, dapat disajikan data Realisasi APBD Kabupaten Morowali tahun 2011-2015 pada tabel 1 berikut:

Tabel 1 Realisasi APBD Kabupaten Morowali Tahun Anggaran 2011-2015

\begin{tabular}{|l|c|c|c|c|c|}
\hline \multicolumn{1}{|c|}{ URAIAN } & $\mathbf{2 0 1 1}$ & $\mathbf{2 0 1 2}$ & $\mathbf{2 0 1 3}$ & $\mathbf{2 0 1 4}$ & $\mathbf{2 0 1 5}$ \\
\hline Pendapatan & \multicolumn{5}{|c|}{$\mid$} \\
\hline PAD & $20,431,217,116$ & $30,528,399,177$ & $39,134,372,089$ & $5,341,127,905$ & $74,439,927,381$ \\
\hline P. Transfer & $623,566,996,546$ & $736,950,390,328$ & $853,144,963,313$ & $6,987,919,910$ & $750,296,510,181$ \\
\hline $\begin{array}{l}\text { Lain-lain } \\
\text { Pendapatan } \\
\text { yang sah }\end{array}$ & $19,793,524,000$ & $2,258,716,504$ & $2,173,800,500$ & $1,138,885,875$ & $10,391,540,469$ \\
\hline T. Pendapatan & $663,791,737,662$ & $769,737,506,009$ & $894,453,135,902$ & $3,467,933,690$ & $835,127,978,031$ \\
\hline Belanja & $347,752,391,257$ & $421,851,459,006$ & $447,947,913,475$ & $9,116,062,984$ & $355,375,802,204$ \\
\hline B. langsung & $244,972,150,716$ & $322,736,257,400$ & $410,094,472,985$ & $5,027,506,716$ & $424,119,779,805$ \\
\hline $\begin{array}{l}\text { B. tidak } \\
\text { langsung }\end{array}$ & & & & & \\
\hline T. Belanja & $592,724,541,973$ & $744,587,716,406$ & $858,042,386,460$ & $4,143,569,699$ & $779,495,582,009$ \\
\hline Surplus/Defisit & $71,067,195,689$ & $25,149,789,603$ & $36,410,749,442$ & $(675,636,009)$ & $55,632,396,022$ \\
\hline
\end{tabular}

Sumber: Badan Pengelolaan Keuangan dan Asset Daerah (BPKAD) Kabupaten Morowali

Berdasarkan tabel 1 dapat dilihat tingkat penerimaan PAD dalam lima tahun terakhir relatif lebih kecil jika dibandingkan Pendapatan Transfer yang mencerminkan rendahnya kemampuan pemerintah daerah dalam menggali sumber-sumber pendapatan asli daerah. Sedangkan jika dilihat secara keseluruhan realisasi pendapatan dan belanja daerah Kabupaten Morowali terus mengalami peningkatan selama 5 tahun terakhir. Namun pada tahun 2014 pendapatan dan belanja daerah memiliki nilai rendah yang merupakan dampak dari ditetapkannya Peraturan Pemerintah No 1 tahun 2014 Tentang Pelarangan Ekspor Bahan Mineral Mentah yang dibarengi dengan pemekaran wilayah Kabupaten Morowali.

Pertumbuhan tingkat pendapatan dan belanja daerah pada tahun 2011-2015 berfluktuasi dari tahun ke tahun dengan rata-rata pertumbuhan pendapatan sebesar 15,37\%. Keberhasilan PemDa belum cukup dengan hanya melihat pertumbuhan pendapatan, tetapi tingkat pertumbuhan belanja juga perlu dilihat nilainya. Rata-rata pertumbuhan belanja daerah yaitu $15,13 \%$ dengan tingkat pertumbuhan teringgi pada tahun 2015 sebesar 64,40\% dan pertumbuhan belanja yang terendah pada tahun 2014 sebesar $-44,74 \%$.

Analisis kinerja Anggaran Pendapatan Belanja Daerah (APBD) adalah suatu proses penilaian mengenai tingkat kemajuan pencapaian pelaksanaan kegiatan dalam bidang keuangan untuk periode 
waktu tertentu. Kinerja pemerintahan menunjukan bagaimana pelaksanaan dari otonomi daerah tersebut berjalan, sehingga hal tersebut sangat penting sebagai tolok ukur keberhasilan (Saputra, et. al: 2016).

Berdasarkan uraian yang dikemukakan, maka peneliti tertarik untuk melakukan penelitian pada Pemerintah Kabupaten Morowali selama lima tahun terakhir yaitu tahun 2011-2015, dengan mengangkat judul "Analisis Kinerja Anggaran Pendapatan Belanja Daerah (APBD) Kabupaten Morowali pada periode tahun 2011-2015 "., dengan tujuan penelitian:

1. Untuk mengetahui kinerja pendapatan Kabupaten Morowali periode tahun 2011-2015 dengan menggunakan Analisis Varians Pendapatan.

2. Untuk mengetahui kinerja pendapatan Kabupaten Morowali periode tahun 2011-2015 dengan menggunakan Analisis Rasio Keuangan Daerah.

3. Untuk mengetahui kinerja belanja daerah Kabupaten Morowali periode tahun 2011-2015 dengan menggunakan Analisis Varians Belanja Daerah.

4. Untuk mengetahui kinerja belanja daerah Kabupaten Morowali periode tahun 2011-2015 dengan menggunakan Analisis Keserasian Belanja.

5. Untuk mengetahui kinerja belanja daerah Kabupaten Morowali periode tahun 2011-2015 dengan menggunakan Analisis Efisiensi Belanja Daerah.

\section{KAJIAN LITERATUR DAN PENGEMBANGAN HIPOTESIS Otonomi Daerah}

Undang-Undang No. 32 Tahun 2004 pasal 1 menyebutkan bahwa Otonomi daerah adalah hak, wewenang, dan kewajiban daerah otonom untuk mengatur dan mengurus sendiri urusan pemerintahan dan kepentingan masyarakat setempat sesuai dengan peraturan perundang-undangan.

\section{Good Governance}

Menurut Santosa (2008:131) good governance mengandung arti hubungan sinergis dan kontruktif di antara pemerintah, sektor swasta, dan masyarakat guna mengembangkan produktivitas ekonomi, efektifitas, dan efisiensi.

\section{Anggaran Pendapatan Belanja Daerah (APBD).}

APBD merupakan ruang lingkup keuangan daerah yang dikelola langsung dan merupakan inti keuangan pemerintahan yang memberikan informasi mengenai keuangan daerah (Hariadi, et.al 2010:3). APBD merupakan satu kesatuan yang terdiri dari pendapatan daerah, belanja daerah dan pembiayaan daerah (Yani, 2008:371):

\section{Analisis Kinerja Keuangan Daerah}

Menurut Saputra, et. al (2016), Keuangan daerah adalah semua hak dan kewajiban daerah dalam rangka penyelenggaraan pemerintah daerah yang dapat dinilai dengan uang termasuk didalamnya segala bentuk kekayaan yang berhubungan dengan hak dan kewajiban tersebut. Menurut Mahmudi (2010:135) Analisis Kinerja Keuangan Pemerintah Daerah dapat dilakukan dengan dua cara yaitu:

1. Analisis Kinerja Pendapatan Daerah

a. Analisis varians pendapatan daerah merupakan selisih antara realisasi pendapatan dengan anggaran pendapatan.

b. Analisis Rasio Keuangan Daerah yang terdiri dari derajat desentralisasi, rasio kemandirian keuangan daerah, rasio ketergantungan keuangan daerah dan rasio efektifitas PAD

2. Analisis Kinerja Belanja Daerah

a. Analisis Varians Belanja Daerah merupakan analisis terhadap selisih antara realisasi dengan anggaran dari belanja daerah. 


\section{Gramini M.}

b. Analisis Keserasian Belanja Daerah menggambarkan bagaimana pemerintah daerah memprioritaskan alokasi dananya pada belanja secara optimal.

c. Analisis Efisiensi Belanja Daerah berguna untuk mengukur tingkat penghematan anggaran yang dilakukan pemerintah. .

\section{Kerangka Pemikiran}

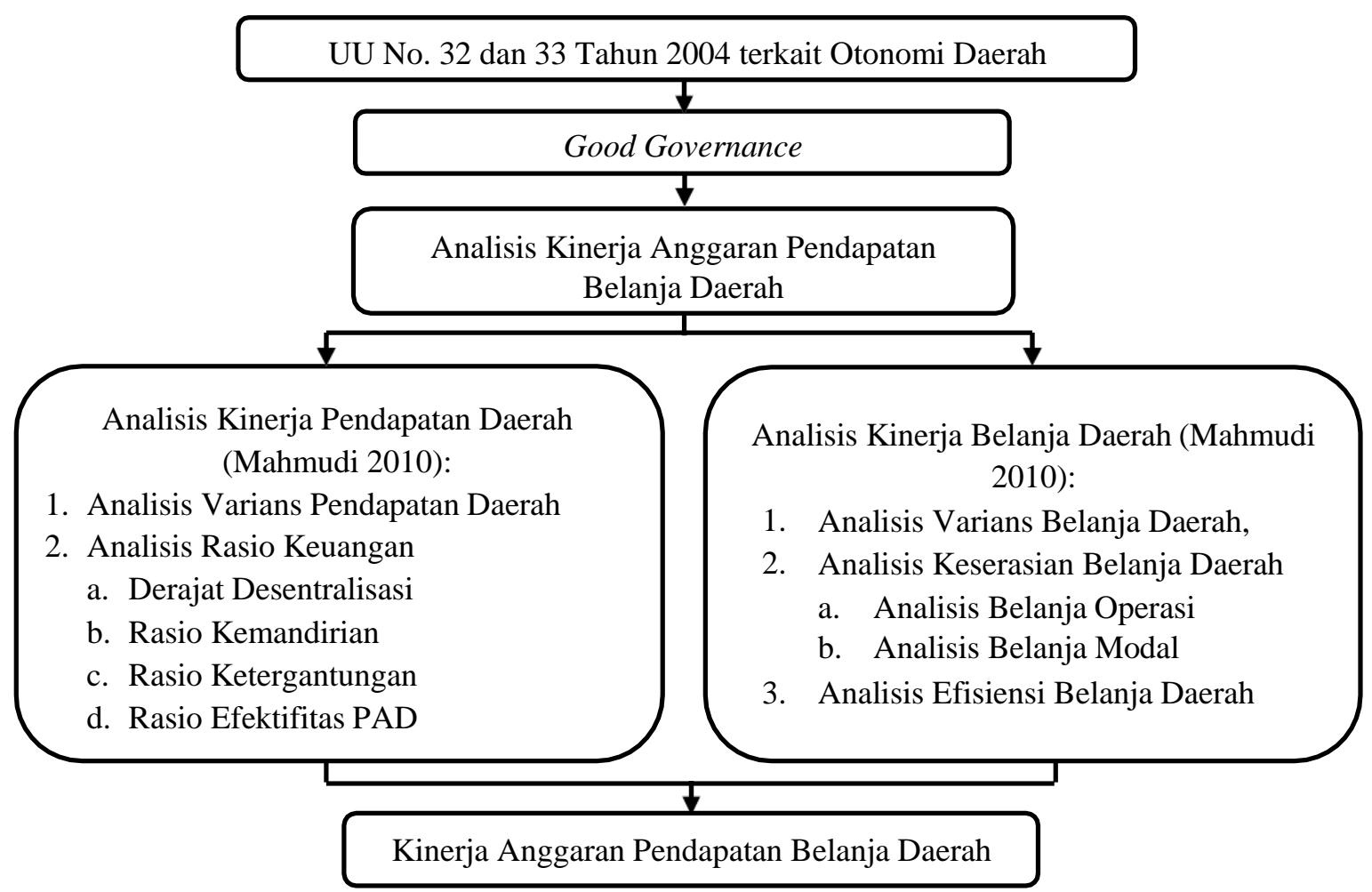

\section{Gambar 1 Kerangka Pemikiran}

\section{METODE PENELITIAN}

Berdasarkan permasalahan yang ada, penelitian ini merupakan penelitian deskriptif kuantitatif yaitu melakukan perhitungan-perhitungan terhadap data keuangan yang diperoleh untuk memecahkan masalah yang ada sesuai dengan tujuan penelitian.

Alat Analisis

a. Analisis Varians Pendapatan Daerah

Analisis kemampuan pemerintah daerah dalam mencapai pendapatan sesuai dengan yang dianggarkan. Menurut Mahmudi (2010:136) Kinerja pendapatan daerah dikatakan baik apabila realisasi pendapatan sama dengan atau bahkan melebihi jumlah yang dianggarkan atau sebaliknya. Rumus:

$$
\text { arians en apatan }=\text { Realisasi Pendapatan }- \text { Anggaran Pendapatan }
$$

b. Analisis Rasio Keuangan Daerah

1. Derajat Desentralisasi menunjukkan kemampuan PemDa untuk menggali dan mengelola pendapatan dalam rangka pelaksanaan desentralisasi (Mahmudi, 2010:142). Rumus: 
Menurut Tim Litbang Depdagri-Fisipol UGM, 1991 dalam Bisma dan Susanto (2010) derajat desentralisasi dikategorikan sebagai berikut:
1. Sangat Kurang : $0,00-10.00 \%$
2. Kurang : $10,01-20,00 \%$
3. Cukup : $20,01-30,00 \%$
4. Sedang : $30,01-40,00 \%$
5. Baik : $40,01-50,00 \%$
6. Sangat Baik : $>50,00 \%$

2. Rasio Kemandirian Keuangan Daerah menunjukkan tingkat kemampuan daerah dalam membiayai sendiri kegiatan pemerintah (Mahmudi 2010:142). Rumusnya sebagai berikut:

Pedoman menurut Halim (2002:189) dalam melihat pola hubungan dengan kemampuan keuangan daerah dapat dikemukakan sebagai berikut:
a. $0 \%-25 \%$ : Rendah Sekali dengan pola hubungan Instruktif
b. $>25 \%-50 \%$ : Rendah dengan pola hubungan Konsultatif
c. $>50 \%-75 \%$ : Sedang dengan pola hubungan Partisipatif
d. $>75 \%$ : Tinggi dengan pola hubungan Delegatif

Berikut ini pola hubungan menurut Paul Hersey dan Kenneth Blanchard dalam Halim (2002:188) yang digunakan dalam pelaksanaan otonomi daerah:

a) Pola hubungan instruktif, di mana peranan pemerintah pusat lebih dominan dari pada kemandirian pemerintah daerah (daerah yang tidak mampu melaksanakan otonomi daerah).

b) Pola hubungan konsultatif, yaitu campur tangan pemerintah pusat sudah mulai berkurang karena daerah dianggap sedikit lebih mampu melaksanakan otonomi daerah.

c) Pola hubungan partisipatif, peranan pemerintah pusat sudah mulai berkurang, mengingat daerah tingkat kemandiriannya mendekati mampu melaksanakan urusan otonomi daerah.

d) Pola hubungan delegatif, yaitu campur tangan pemerintah pusat sudah tidak ada karena daerah telah benar-benar mampu dan mandiri dalam melaksanakan urusan otonomi daerah.

3. Rasio Ketergantungan Daerah mengukur tingkat ketergantungan pemerintah daerah terhadap Pemerintah Pusat/Provinsi dalam penyelenggaraan desentalisasi (Mahmudi, 2010:142). Rumus:

Menurut Tim Litbang Depdagri-Fisipol UGM, 1991 dalam Bisma dan Susanto (2010) nilai ketergantungan keuangan daerah dikategorikan sebagai berikut:
1. Sangat Rendah
: $0,00-10.00 \%$
2. Rendah
: $10,01-20,00 \%$
3. Cukup
: $20,01-30,00 \%$
4. Sedang
: $30,01-40,00 \%$
5. Tinggi
: $40,01-50,00 \%$
6. Sangat Tinggi
:> $50,00 \%$ 


\section{Gramini M.}

4. Rasio Efektifitas Pendapatan Asli Daerah untuk mengukur kemampuan PemDa dalam memperoleh PAD sesuai dengan yang ditargetkan (Mahmudi, 2010:143). Rumus:

Kriteria penilaian efektifitas PAD (Mahmudi, 2010:143) dikategorikan berikut:

1. Sangat Efektif : Lebih dari $100 \%$

2. Efektif : $: 100 \%$

3. Cukup Efektif : $90 \%$ sampai $99 \%$

4. Kurang Efektif : $75 \%$ sampai $89 \%$

5. Tidak Efektif : Kurang dari $75 \%$

\section{c. Analisis Varians Belanja Daerah}

Apabila belanja daerah melampaui batas maksimum (anggaran) maka kinerjanya dinilai kurang baik (Mahmudi, 2010:157).

Varians Belanja = Anggaran Belanja - Realisasi Belanja

\section{d. Analisis Keserasian Belanja Daerah}

Analisis Keserasian Belanja menggambarkan bagaimana pemerintah daerah memprioritaskan alokasi dananya pada belanja operasional dan belanja modal secara optimal (Mahmudi, 2010:162). Rasio Belanja operasi merupakan tingkat perbandingan antara belanja operasi terhadap total belanja daerah, sedangkan Rasio Belanja modal merupakan tingkat perbandingan antara belanja modal terhadap total belanja daerah. Menurut Mahsun, 2006 dalam Batafor (2011) nilai Keserasian Belanja Daerah dikategorikan berikut:

1. Tidak Serasi : $0 \%-20 \%$

2. Kurang Serasi : $>20 \%-40 \%$

3. Cukup Serasi : $>40 \%-60 \%$

4. Serasi : $>60 \%-80 \%$

5. Sangat Serasi : $>80 \%-100 \%$

\section{e. Analisis Efisiensi Belanja Daerah}

Rasio ini berguna untuk mengukur tingkat penghematan anggaran yang dilakukan pemerintah. Pemerintah daerah di nilai telah melakukan efisiensi anggaran jika rasio efisiensinya kurang dari 100\% atau sebaliknya (Mahmudi, 2010:166). Rasio efisiensi dapat dirumuskan sebagai berikut:

\section{HASIL DAN PEMBAHASAN \\ HASIL PENELITIAN \\ Deskriptif Pendapatan Asli Daerah}

Pendapatan Asli Daerah merupakan seluruh pendapatan yang berasal dari potensi riil daerah dan pengelolaanya dilakukan sendiri oleh daerah. 
Tabel 2 Tingkat Pendapatan Asli Daerah Kabupaten Morowali Tahun 2011-2015

\begin{tabular}{|c|c|r|r|r|}
\hline Tahun & Pajak daerah & Retribusi daerah & \multicolumn{1}{c|}{ HPKYD } & $\begin{array}{c}\text { Lain-lain PAD yang } \\
\text { sah }\end{array}$ \\
\hline 2011 & $3.077 .845 .753,80$ & $11.282 .840 .342,13$ & $1.847 .791 .562,00$ & $4.222 .739 .457,63$ \\
\hline 2012 & $5.019 .172 .911,54$ & $20.624 .630 .407,72$ & $497.692 .721,65$ & $4.386 .903 .136,49$ \\
\hline 2013 & $6.077 .099 .002,42$ & $22.410 .356 .598,61$ & $901.793 .357,13$ & $9.745 .123 .131,32$ \\
\hline 2014 & $5.478 .277 .179,05$ & $11.198 .336 .426,00$ & $806.416 .985,20$ & $7.858 .097 .314,53$ \\
\hline 2015 & $9.253 .913 .898,33$ & $23.904 .258 .916,00$ & $1.784 .645 .429,17$ & $39.497 .109 .137,43$ \\
\hline
\end{tabular}

Sumber: BPKAD Kabupaten Morowali (diolah 2016)

\section{Deskriptif Belanja Daerah}

Belanja daerah meliputi semua pengeluaran uang dari rekening kas umum daerah yang mengurangi ekuitas dana lancar, dan merupakan kewajiban dalam 1 tahun anggaran yang tidak akan diperoleh pembayaranya kembali oleh daerah. Berikut tingkat belanja daerah Kebupaten Morowali:

Tabel 3 Tingkat Belanja Daerah Kebupaten Morowali Tahun 2011-2015

\begin{tabular}{|c|r|r|r|r|}
\hline Tahun & Belanja Operasi & Belanja Modal & \multicolumn{1}{c|}{$\begin{array}{c}\text { Belanja Tak } \\
\text { Terduga }\end{array}$} & Belanja Daerah \\
\hline 2011 & $467.695 .289 .761,00$ & $124.021 .479 .535,00$ & $1.007 .772 .677,00$ & $592.724 .541 .973,00$ \\
\hline 2012 & $569.609 .862 .188,00$ & $173.763 .263 .121,00$ & $1.214 .591 .097,00$ & $744.587 .716 .406,00$ \\
\hline 2013 & $657.888 .068 .548,80$ & $199.252 .251 .912,00$ & $902.066 .000,00$ & $858.042 .386 .460,80$ \\
\hline 2014 & $361.708 .026 .733,92$ & $111.639 .822 .666,00$ & $795.720 .300,00$ & $474.143 .569 .699,92$ \\
\hline 2015 & $535.827 .568 .760,40$ & $242.421 .907 .862,66$ & $1.246 .105 .386,00$ & $779.495 .582 .009,06$ \\
\hline
\end{tabular}

Sumber: BPKAD Kabupaten Morowali (diolah 2016)

\section{Analisis Kinerja Pendapatan Daerah}

1. Analisis Varians Pendapatan Daerah

Analisis varians pendapatan daerah menggambarkan kemampuan daerah dalam merealisasikan pendapatan daerah yang telah dianggarkan. Hasil dari perhitungan varians pendapatan daerah:

Tabel 4 Penghitungan Varians Pendapatan Daerah Kabupaten Morowali Tahun Anggaran 2011-2015

\begin{tabular}{|c|c|c|c|c|}
\hline Tahun & Anggaran (Rp) & Realisasi (Rp) & Varians/Selisih (Rp) & Kinerja \\
\hline 2011 & $706.050 .216 .022,49$ & $663.791 .737 .661,56$ & $-42.258 .478 .360,93$ & Kurang Baik \\
\hline 2012 & $791.374 .889 .217,00$ & $769.737 .506 .009,40$ & $-21.637 .383 .207,60$ & Kurang Baik \\
\hline 2013 & $889.637 .943 .153,09$ & $894.453 .135 .902,48$ & $4.815 .192 .749,39$ & Baik \\
\hline 2014 & $520.533 .195 .831,00$ & $473.467 .933 .689,78$ & $-47.065 .262 .141,22$ & Kurang Baik \\
\hline 2015 & $947.046 .939 .703,00$ & $835.127 .978 .031,19$ & $-111.918 .961 .671,81$ & Kurang Baik \\
\hline & -43612978 & Baik \\
\hline
\end{tabular}

Sumber: BPKAD Kabupaten Morowali (diolah:2016) dan Mahmudi (2010:136)

Berdasarkan perhitungan pada Tabel 4 menunjukkan bahwa varians pendapatan daerah Kabupaten Morowali secara keseluruhan memiliki rata-rata sebesar Rp. -43.612.978.526,43 yang berarti kinerja pendapatan daerah kurang baik. Hal ini menunjukkan bahwa kinerja pendapatan Kabupaten Morowali secara keseluruhan belum mampu merealisasikan anggaran pendapatan. Dilihat dari analisis varians pendapatan, pada tahun 2011 dan 2012 realisasi pendapatan Kabupaten Morowali dinilai kurang baik karena realisasi pendapatan yang dicapai kurang dari anggaran yang ditetapkan. Hal ini disebabkan karena terjadi ketidakefektifan dalam pengelolaan PAD yang menyebabkan rendahnya kontribusi PAD terhadap pendapatan daerah. Akan tetapi di tahun 2013 dilihat dari varians pendapatan, kinerja pendapatan daerah Kabupaten Morowali dinilai baik yang berarti bahwa pemerintah daerah mampu 
mencapai anggaran pendapatan yang telah ditetapkan. Hal ini menunjukkan terjadi peningkatan penerimaan PAD yang dibarengi pula dengan peningkatan pendarapatan transfer. Kinerja pendapatan daerah Kabupaten Morowali pada tahun 2014 dan 2015 jika dilihat dari varians pendapatan daerah dinilai kurang baik karena ketidakmampuan pemerintah daerah dalam merealisasikan anggaran pendapatan. 2. Rasio Keuangan Daerah

a. Derajat Desentralisasi

Rasio ini menunjukkan pelimpahan tanggung jawab dari pemerintah pusat kepada pemerintah daerah untuk menggali dan mengelola pendapatan. Hasil dari perhitungan derajat desentralisasi:

Tabel 5 Perhitungan Derajat Desentralisasi Kabupaten Morowali Tahun Anggaran 2011-2015

\begin{tabular}{|c|c|c|c|c|}
\hline Tahun & PAD & \begin{tabular}{ll|} 
Total & Pendapatan \\
Daerah & \\
\end{tabular} & Rasio & Kinerja \\
\hline 2011 & 20.431 .217 .116 & 663.791 .737 .662 & $3,08 \%$ & Sangat Kurang \\
\hline 2012 & 30.528 .399 .177 & 769.737 .506 .009 & $3,97 \%$ & Sangat Kurang \\
\hline 2013 & 39.134 .372 .089 & 894.453 .135 .902 & $4,38 \%$ & Sangat Kurang \\
\hline 2014 & 25.341 .127 .905 & 473.467 .933 .690 & $5,35 \%$ & Sangat Kurang \\
\hline 2015 & 74.439.927.381 & 835.127 .978 .031 & $8,91 \%$ & Sangat Kurang \\
\hline \multicolumn{3}{|c|}{ Rata-Rata } & $5,14 \%$ & Sangat Kurang \\
\hline
\end{tabular}

Sumber: BPKAD Kabupaten Morowali (diolah: 2016) dan Tim Litbang Depdagri-Fisipol UGM, 1991 dalam Bisma dan Susanto (2010)

Berdasarkan perhitungan derajat desentralisasi dalam Tabel 5 terlihat bahwa derajat desentralisasi Kabupaten Morowali dinilai sangat kurang. Hal ini berarti bahwa rendahnya kontribusi Pendapatan Asli Daerah terhadap Total Pendapatan Daerah dan rendahnya peran PAD atau kemampuan keuangan daerah dalam membiayai sendiri kegiatan pemerintahan masih cenderung bergatung pada DAU. Rendahnya kontribusi PAD disebabkan karena masih rendahnya kinerja pemungutan pajak daerah dan ketidakefektifan daerah dalam mengelola pendapatan asli daerahnya dalam rangka pelaksanaan desentralisasi.

Berdasarkan standar penilaian menurut Tim Litbang Depdagri-Fisipol UGM, 1991 dalam Bisma dan Susanto (2010) persentase derajat desentralisasi Kabupaten Morowali secara keseluruhan dinilai sangat kurang, tetapi dari tahun ke tahun derajat desentralisasi terus mengalami peningkatan. Derajat desentralisasi yang dinilai sangat kurang akan berdampak pada melambannya pembangunan daerah Kabupaten Morowali.

b. Rasio Kemandirian Keuangan Daerah.

Rasio ini digunakan untuk melihat tingkat perbandingan antara PAD dengan Pendapatan Transfer yang menunjukkan tingkat kemampuan daerah dalam membiayai sendiri kegiatan pemerintah. Berikut ini merupakan tabel perhitungan rasio kemandirian daerah:

Tabel 6 Perhitungan Tingkat Kemandirian Keuangan Daerah Kabupaten Morowali Tahun Anggaran 2011-2015

\begin{tabular}{|c|c|c|c|c|c|}
\hline Tahun & PAD & $\begin{array}{c}\text { Pendapatan } \\
\text { Transfer }\end{array}$ & Rasio & Kinerja & $\begin{array}{c}\text { Pola } \\
\text { Hubungan }\end{array}$ \\
\hline 2011 & 20.431 .217 .116 & 623.566 .996 .546 & $3,28 \%$ & Rendah Sekali & Instruktif \\
\hline 2012 & 30.528 .399 .177 & 736.950 .390 .328 & $4,14 \%$ & Rendah Sekali & Instruktif \\
\hline 2013 & 39.134 .372 .089 & 853.144 .963 .313 & $4,59 \%$ & Rendah Sekali & Instruktif \\
\hline 2014 & 25.341 .127 .905 & 446.987 .919 .910 & $5,67 \%$ & Rendah Sekali & Instruktif \\
\hline 2015 & 74.439 .927 .381 & 750.296 .510 .181 & $9,92 \%$ & Rendah Sekali & Instruktif \\
\hline \multicolumn{7}{|r|}{ Rata-Rata } & $\mathbf{5 , 5 2 \%}$ & Rendah Sekali & Instruktif \\
\hline
\end{tabular}

Sumber: BPKAD Kabupaten Morowali (diolah: 2016) dan Halim (2002:189) 
Berdasarkan standar penilaian menurut Halim (2002:189) hasil ini menunjukkan bahwa dalam pelaksanaan otonomi daerah Kabupaten Morowali memiliki tingkat kemandirian yang rendah sekali dangan pola hubungan instruktif. Hal ini mengindikasikan bahwa Kabupaten Morowali belum mampu melaksanakan otonomi daerah, dimana peranan pemerintah lebih dominan daripada kemandirian pemerintah daerah. Rendahnya rasio kemandirian disebabkan karena PAD Kabupaten Morowali masih sangat rendah jika di bandingkan dengan pendapatan transfer. Rendahnya tingkat kemandirian daerah Kabupaten Morowali akan berdampak pada tingkat pelayanan kepada masyarakat. Hal ini disebabkan karena PAD Kabupaten Morowali belum dapat dihandalkan melayani masyarakatnya dan masih bergantung pada pendapatan transfer.

c. Rasio Ketergantungan Keuangan Daerah

Rasio ini menunjukan tingkat ketergantungan pemerintah daerah terhadap pemerintah pusat/provinsi dalam pelaksanaan desentralisasi. Berikut ini tabel perhitungan rasio ketergantungan:

Tabel 7 Perhitungan Tingkat Ketergantungan Keuangan Daerah Kabupaten Morowali Tahun Anggaran 2011-2015

\begin{tabular}{|c|c|c|c|c|}
\hline Tahun & $\begin{array}{c}\text { Pendapatan } \\
\text { Transfer }\end{array}$ & \begin{tabular}{|ll} 
Total & Pendapatan \\
Daerah &
\end{tabular} & Rasio & Kinerja \\
\hline 2011 & 623.566 .996 .546 & 663.791 .737 .662 & $93,94 \%$ & Sangat Tinggi \\
\hline 2012 & 736.950 .390 .328 & 769.737.506.009 & $95,74 \%$ & Sangat Tinggi \\
\hline 2013 & 853.144 .963 .313 & 894.453 .135 .902 & $95,38 \%$ & Sangat Tinggi \\
\hline 2014 & 446.987 .919 .910 & 473.467 .933 .690 & $94,41 \%$ & Sangat Tinggi \\
\hline 2015 & 750.296 .510 .181 & 835.127 .978 .031 & $89,84 \%$ & Sangat Tinggi \\
\hline \multicolumn{3}{|c|}{ Rata-Rata } & $93,86 \%$ & Sangat Tinggi \\
\hline
\end{tabular}

Sumber: BPKAD Kabupaten Morowali (diolah: 2016) Tim Litbang Depdagri-Fisipol UGM, 1991 dalam Bisma dan Susanto (2010)

Berdasarkan Tabel 7 perhitungan rasio ketergantungan keuangan daerah dapat dikatakan bahwa tingkat ketergantungan Kabupaten Morowali cenderung berfluktuasi dengan rata-rata 93,86\% berarti tingkat ketergantungan dinilai sangat tinggi. Hal ini disebabkan karena besarnya tingkat pendapatan transfer khususnya DAU yang diterima Kabupaten Morowali. Hasil ini menunjukkan bahwa terdapat tingkat ketergantungan Kabupaten Morowali yang sangat tinggi terhadap pemerintahan pusat/provinsi dalam pelaksanaan desentralisasi. Tingginya tingkat ketergantungan daerah Kabupaten Morowali kepada pemerintah pusat akan memberikan dampak pada rendahnya kemandirian daerah dalam hal pelayanan masyarakat dan pembangunan daerahnya.

d. Rasio Efektifitas Pendapatan Asli Daerah

Rasio Efektifitas PAD menggambarkan kemampuan pemerintah daerah dalam memobilisasi penerimaan PAD yang ditetapkan berdasarkan potensi riil daerah. Berikut tingkat Efektifitas PAD:

Tabel 8 Perhitungan Tingkat Efektifitas Pendapatan Asli Daerah Kabupaten Morowali Tahun Anggaran 2011-2015

\begin{tabular}{|c|c|c|c|c|}
\hline Tahun & Anggaran PAD & Realisasi PAD & Rasio & Kinerja \\
\hline 2011 & $46.947 .535 .901,49$ & $20.431 .217 .115,56$ & $43,52 \%$ & Tidak Efektif \\
\hline 2012 & $45.800 .100 .353,00$ & $30.528 .399 .177,40$ & $66,66 \%$ & Tidak Efektif \\
\hline 2013 & $48.578 .791 .578,09$ & $39.134 .372 .089,48$ & $80,56 \%$ & Kurang Efektif \\
\hline 2014 & $39.528 .894 .781,00$ & $25.341 .127 .904,78$ & $64,11 \%$ & Tidak Efektif \\
\hline 2015 & $81.010 .135 .335,00$ & $74.439 .927 .380,93$ & $91,89 \%$ & Cukup Efektif \\
\hline \multicolumn{3}{|c|}{ Rata-Rata } & $69,35 \%$ & Tidak Efektif \\
\hline
\end{tabular}

Sumber: BPKAD Kabupaten Morowali (diolah: 2016) dan Mahmudi (2010:143) 
Berdasarkan Tabel 8 di atas secara umum rasio efektifitas PAD masih termasuk dalam ketegori tidak efektif karena memiliki rata-rata $69,35 \%$. Berdasarkan standar penilaian menurut Mahmudi (2010:143) menunjukkan bahwa pada tahun 2015 memiliki nilai efektifitas tertinggi yaitu sebesar 91,89\% berarti bahwa pemerintah daerah Kabupaten Morowali cukup efektif dalam menggali dan mengelola PAD. Hal ini disebabkan karena pada tahun 2015 telah diresmikan pengoperasian smelter untuk mengelolaan mineral mentah serta Kabupaten Morowali menerima dana BLUD dan BLUD APBD yang mempengaruhi total penerimaan PAD. Lain halnya pada tahun 2011, pada tahun ini tingkat efektifitas PAD menunjukkan nilai yang tidak efektif yaitu sebesar 43,52\% karena masih $>75 \%$, begitu pula yang terjadi di tahun 2012 dan 2014, karena yang menjadi masalah umum dalam memobilisasi penerimaan

PAD adalah ketidakefektifan dalam mengelola potensi riil daerah guna meningkatkan PAD. Sedangkan di tahun 2013 efektifitas PAD cenderung lebih membaik dari tahun sebelumnya yaitu termasuk dalam kategori kurang efektif

\section{Analisis Kinerja Belanja Daerah}

1. Analisis Varians Belanja Daerah

Analisis varians belanja merupakan selisih antara anggaran belanja dan realisasi belanja. Berikut ini tabel perhitungan analisis varians belanja daerah Kabupaten Morowali:

Tabel 9 Perhitungan Varians Belanja Daerah Kabupaten Morowali Tahun Anggaran 2011-2015

\begin{tabular}{|c|c|c|c|c|}
\hline Tahun & Anggaran & Realisasi & Varians/Selisih (Rp) & Kinerja \\
\hline 2011 & $666.674 .470 .640,11$ & $592.724 .541 .973,00$ & $73.949 .928 .667,11$ & Baik \\
\hline 2012 & $813.502 .012 .839,00$ & $744.587 .716 .406,00$ & $68.914 .296 .433,00$ & Baik \\
\hline 2013 & $900.678 .253 .858,00$ & $858.042 .386 .460,80$ & $42.635 .867 .397,20$ & Baik \\
\hline 2014 & $582.601 .471 .115,00$ & $474.143 .569 .699,92$ & $108.457 .901 .415,08$ & Baik \\
\hline 2015 & $865.655 .404 .672,00$ & $779.495 .582 .009,06$ & $86.159 .822 .662,94$ & Baik \\
\hline \multicolumn{3}{|c|}{ Rata-Rata } & $76.023 .563 .315,07$ & Baik \\
\hline
\end{tabular}

Sumber: BPKAD Kabupaten Morowali (diolah: 2016) dan Mahmudi (2010:157)

Berdasarkan Tabel 9 analisis varians belanja daerah Secara umum berdasarkan kriteria penilaian menurut Mahmudi (2010: 157) yang dilihat dari varians belanja daerah menunjukkan bahwa kinerja belanja Kabupaten Morowali dapat dinilai baik yang berarti bahwa daerah Kabupaten Morowali mampu memanfaatkan dan mengendalikan anggaran belanja agar tidak melebihi anggaran yang ditetapkan.

Varians belanja tertinggi terjadi pada tahun 2014 disebabkan menurunnya belanja pegawai yang dikeluarkan oleh pemerintah daerah akibat dari pemekaran wilayah dimana sebagian pegawainya dipindah tugaskan ke Kabupaten yang baru. Varians terendah terjadi pada tahun 2013 disebabkan karena besarnya pengeluaran untuk pembelian barang dan jasa yang dikeluarkan dalam bentuk ongkos perjalanan dinas yang dianggarkan setiap tahunnya serta tingginya belanja pegawai.

2. Analisis Keserasian Belanja Daerah

Analisis Keserasian Belanja Daerah bermanfaat untuk mengetahui keseimbangan alokasi dana belanja daerah. Berikut ini tabel perhitungan tingkat keserasian belanja daerah Kabupaten Morowali: 
Tabel 10

Perhitungan Analisis Keserasian Belanja Daerah Kabupaten Morowali Tahun Anggaran 2011-2015

\begin{tabular}{|c|c|c|c|c|}
\hline \multirow{2}{*}{ Tahun } & \multirow{2}{*}{$\begin{array}{c}\text { Belanja Operasi } \\
\text { Terhadap Total Belanja }\end{array}$} & \multirow{2}{*}{$\begin{array}{c}\text { Belanja Modal } \\
\text { terhadap Total Belanja }\end{array}$} & \multicolumn{2}{|c|}{ Rasio Keserasian } \\
\hline & & & Belanja Operasi & Belanja Modal \\
\hline \multirow{2}{*}{2011} & $467.695 .289 .761,00$ & $124.021 .479 .535,00$ & $\underline{78,91 \%}$ & $\underline{20,92 \%}$ \\
\hline & $592.724 .541 .973,00$ & $592.724 .541 .973,00$ & Serasi & Kurang Serasi \\
\hline \multirow{2}{*}{2012} & $569.609 .862 .188,00$ & $173.763 .263 .121,00$ & $\underline{76,50 \%}$ & $\underline{23,34 \%}$ \\
\hline & $744.587 .716 .406,00$ & $744.587 .716 .406,00$ & Serasi & Kurang Serasi \\
\hline \multirow{2}{*}{2013} & $657.888 .068 .548,80$ & $199.252 .251 .912,00$ & $\underline{76,67 \%}$ & $23,22 \%$ \\
\hline & $858.042 .386 .460,80$ & $858.042 .386 .460,80$ & Serasi & Kurang Serasi \\
\hline \multirow{2}{*}{2014} & $361.708 .026 .733,92$ & $111.639 .822 .666,00$ & $\underline{76,29 \%}$ & $\underline{23,55 \%}$ \\
\hline & $474.143 .569 .699,92$ & $474.143 .569 .699,92$ & Serasi & Kurang Serasi \\
\hline \multirow{2}{*}{2015} & $535.827 .568 .760,40$ & $242.421 .907 .862,00$ & $\underline{68,74 \%}$ & $\underline{31,10 \%}$ \\
\hline & $779.495 .582 .009,06$ & 779.495.582.009,06 & Serasi & Kurang Serasi \\
\hline \multicolumn{3}{|c|}{ Rata-Rata } & $\frac{75.42 \%}{\text { Serasi }}$ & $\frac{24.43 \%}{\text { Kurang Serasi }}$ \\
\hline
\end{tabular}

Sumber: BPKAD Kabupaten Morowali (diolah: 2016) dan Mahsun, 2006 dalam Batafor (2011)

Berdasarkan tabel perhitungan di atas dapat terlihat bahwa selama tahun 2011-2015 Kabupaten Morowali cenderung lebih mengalokasikan belanja daerahnya untuk belanja operasi dibandingkan belanja modal sehingga rasio belanja modal relatif lebih kecil. Selama tahun 2011-2015 rata-rata belanja operasi sebesar 75,42\% sedangkan untuk belanja modal sebesar $24,43 \%$.

Rata-rata alokasi belanja operasi yaitu sebesar 75,42\% digunakan untuk belanja pegawai, belanja barang dan jasa, belanja bunga, belanja hibah, belanja bantuan sosial dan belanja bantuan keuangan. Dari komponen belanja operasi, belanja pegawai menyerap dana yang besar dari total belanja daerah. Presentase belanja pegawai rata-rata mencapai $47,29 \%$. Jumlah ini jauh lebih besar dari presentase yang digunakan umtuk biaya modal yang hanya rata-rata $24,43 \%$ dari total belanja Kabupaten Morowali. Belanja modal tersebut digunakan untuk belanja tanah, belanja peralatan dan mesin, belanja bangunan dan gedung, belanja jalan, irigasi dan jaringan, serta belanja aset tetap lainnya. Kabupaten Morowali dalam rencana maupun realisasi belanja daerahnya lebih besar porsinya pada belanja oparasi sedangkan untuk penopang pelayanan publik dan penopang ekonomi termasuk belanja modal masih rendah.

3. Analisis Efisiensi Belanja

Rasio efisiensi belanja daerah ini digunakan untuk mengukur tingkat penghematan anggaran yang dilakukan pemerintah daerah. Berikut ini tabel analisis efisiensi belanja daerah:

Tabel 11 Perhitungan Efisiensi Belanja Daerah Kabupaten Morowali Tahun Anggaran 2011-2015

\begin{tabular}{|c|c|c|c|c|}
\hline Tahun & Anggaran Belanja & Realisasi Belanja & Rasio & Kinerja \\
\hline 2011 & $666.674 .470 .640,11$ & $592.724 .541 .973,00$ & $88,91 \%$ & Efisien \\
\hline 2012 & $813.502 .012 .839,00$ & $744.587 .716 .406,00$ & $91,53 \%$ & Efisien \\
\hline 2013 & $900.678 .253 .858,00$ & $858.042 .386 .460,80$ & $95,27 \%$ & Efisien \\
\hline 2014 & $582.601 .471 .115,00$ & $474.143 .569 .699,92$ & $81,38 \%$ & Efisien \\
\hline 2015 & $865.655 .404 .672,00$ & $779.495 .582 .009,06$ & $90,05 \%$ & Efisien \\
\hline \multicolumn{3}{|c|}{ Rata-Rata } & $89,43 \%$ & Efisien \\
\hline
\end{tabular}

Sumber: BPKAD Kabupaten Morowali (diolah: 2016) dan Mahmudi (2010:166) 


\section{Gramini M.}

Berdasarkan Tabel 11 terlihat bahwa efisiensi belanja daerah Kabupaten Morowali berfluktuasi dari tahun ke tahun. Berdasarkan standar penilaian menurut Mahmudi (2010:166) menunjukan bahwa pada tahun 2011 sampai tahun 2015 semua angka pada rasio efisiensi memiliki angka di bawah 100\% dengan rata-rata rasio efesiensi sebesar $89,43 \%$. Hal ini berarti bahwa kinerja belanja daerah Kabupaten Morowali telah melakukan efisiensi belanja atau tidak ada pemborosan dalam penggunaan anggaran belanja pada tahun 2011 sampai tahun 2015.

Tingkat efisiensi belanja daerah dari tahun ke tahun cenderung berfluktuasi. Dari segi nominalnya penggunaan anggaran belanja tertinggi terjadi pada tahun 2013 yang disebabkan kerena sebagian besar anggaran belanja daerah digunakan untuk belanja pegawai serta pembelian barang dan jasa yang dikeluarkan dalam bentuk ongkos perjalanan dinas. Berbeda halnya pada tahun 2014, pada tahun ini penggunaan anggaran mengalami penurunan dan merupakan memiliki tingkat efisiensi yang tinggi karena terjadi pengurangan penggunaan anggaran untuk belanja pegawai.

\section{PEMBAHASAN PENELITIAN}

\section{Analisis Kinerja Pendapatan Daerah}

\section{Analisis Varians Pendapatan Daerah}

Analisis varians pendapatan secara umum menunjukkan bahwa kinerja pendapatan daerah Kabupaten Morowali termasuk dalam ketegori kurang baik. Ditunjukkan dengan sebagian besar tahun yang diteliti mengalami selisih yang benilai negatif atau selisih yang tidak diharapkan dengan rata-rata varians pendapatan sebesar Rp -43.612.978.526,43. Hasil Penelitian ini mendukung pendapat yang dikemukakan oleh Mahmudi (2010:137) yaitu Pemerintah Kabupaten dikatakan memiliki kinerja pendapatan yang kurang baik apabila dapat memperoleh pendapatan yang kurang dari jumlah yang dianggarkan. Dalam hal ini, maka Kabupaten Morowali perlu lebih mengenali sumber-sumber pendapatan yang berpotensi memiliki kontribusi besar tehadap total pendapatan, sehingga pemerintah mampu mencapai anggaran pendapatan yang telah ditetapkan.

\section{Analisis Rasio Keuangan Daerah}

\section{a. Derajat Desentralisasi}

Berdasarkan hasil analisis derajat desentralisasi Kabupaten Morowali dinilai sangat kurang. Besarnya tingkat ketergantungan pemerintah daerah Kabupaten Morowali terhadap pemerintah pusat terutama ditunjukan dengan rendahnya kontribusi PAD terhadap pendapatan daerah, peran PAD atau kemampuan keuangan daerah untuk membiayai sendiri kegiatan pemerintahan masih kurang dari $50 \%$ artinya sangat kurang dan cenderung masih bergantung pada DAU. Peningkatan ini mengindikasikan terjadinya peningkatan kontribusi PAD terhadap pendapatan daerah. Hasil ini mendukung pendapat dari Mahmudi (2010:142) bahwa semakin besar kontribusi PAD maka semakin besar pula kemampuan pemerintah daerah dalam menyelenggarakan desentralisasi.

Penelitian yang dilakukan oleh Bahrun Assidiqi (2014) Kinerja Keuangan Daerah Kabupaten Kalten jika dilihat dari derajat desentralisasi masih tergolong sangat kurang. Penyebab terjadinya hal tersebut hampir sama apa yang dijelaskan pada penelitian ini dimana kedua daerah ini yaitu Kabupaten Klaten dan Kabupaten Morowali masih kurangnya kemampuan pemerintah daerah dalam meningkatkan PAD guna membiayai pembangunan daerah dalam rangka pelaksanaan desentralisasi. Kedua Pemerintah Kabupaten ini diharapkan selalu memaksimalkan potensi PAD yang ada, sehingga mampu membiayai pembangunan daerah dalam rangka pelaksanaan desentralisasi. $b$. Rasio Kemandirian Keuangan Daerah

Berdasarkan kriteria penilaian menurut Halim (2002:189) rasio kemandirian Kabupaten Morowali tergolong rendah sekali dengan pola hubungan instruktif karena masih tergolong dalam interval $0 \% 25 \%$. Hal ini dikarenakan pendapatan transfer dari pemerintah pusat dan provinsi jauh lebih besar dari PAD Kabupaten Morowali. Rasio ini menunjukkan bahwa tingkat kemandirian 
daerah Kabupaten Morowali masih sangat tinggi dengan pola hubungan instruktif yang berarti bahwa peran pemerintah pusat lebih dominan dari pada kemandirian daerah Kabupaten Morowali. Rasio kemandirian yang masih rendah sekali menggambarkan kemampuan daerah Kabupaten Morowali dalam membiayai pelaksanaan pemerintahan daerah masih sangat tergantung pada pemerintah pusat dan menggambarkan tingkat partisipasi masyarakat dalam pembangunan daerah Kabupaten Morowali.

Pada penelitian yang dilakukan oleh Kalalo. et.al (2014) Kinerja Keuangan Daerah Kota Manado jika dilihat dari Rasio Kemandirian tergolong sangat rendah karena pendapatan transfer dari pemerintah pusat/provinsi jauh lebih besar dari Pendapatan Asli Daerah. Hal ini berarti bahwa kedua daerah ini yaitu Kota Manado dan Kabupaten Morowali masih mengandalkan bantuan dari pemerintah baik pusat maupun provinsi dan belum mampu untuk mengolah potensi penerimaan di daerahnya. Kedua Pemerintah Kota Manado maupun Pemerintah Kabupaten Morowali diharapkan selalu memaksimalkan potensi PAD yang ada, sehingga daerah mampu membiayai kegiatan pemerintahan secara mandiri. c. Rasio Ketergantungan Keuangan Daerah

Rasio ketergantungan keuangan daerah Kabupaten Morowali menunjukkan angka rata-rata sebesar 93,86\%. Tingkat ketergantungan Kabupaten Morowali secara keseluruhan berada pada angka $>50 \%$ (sangat tinggi) menunjukkan bahwa Kabupaten Morowali masih sangat tergantung pada pemerintah pusat/provinsi. Hal ini mendukung pendapat Mahmudi (2010:142) bahwa semakin tinggi rasio ketergantungan keuangan daerah maka semakin besar tingkat ketergantungan pemerintah kabupaten terhadap pemerintah pusat.

Pada penelitian yang dilakukan oleh Bahrun Assidiqi (2014) Kinerja Keuangan Daerah Kabupaten Kalten jika dilihat dari rasio ketergantungan tergolong sangat tinggi. Penyebab terjadinya hal tersebut hampir sama apa yang dijelaskan pada penelitian ini dimana kedua daerah ini yaitu Kabupaten Klaten dan Kabupaten Morowali belum mampu membiayai seruluh kegiatanya dan masih bergantung pada pemerintah pusat/provinsi. Kedua Pemerintah Kabupaten Kalten maupun Kabupaten Morowali diharapkan selalu memaksimalkan potensi PAD yang ada, sehingga tidak selalu bergantung pada bantuan dari pusat/provinsi.

d. Rasio Efektifitas Pendapatan Asli Daerah

Rasio Efektifitas PAD Kabupaten Morowali memiliki rata-rata sebesar 69,35\% yang menunjukkan bahwa Kabupaten Morowali sangat tidak efektif dalam membiayai otonomi daerahnya. Ini menunjukkan bahwa PAD belum dapat diandalkan bagi daerah untuk mendukung pelaksanaan otonomi daerah karena kurangnya kemampuan pemerintah daerah dalam menggali potensi daerah untuk meningkatkan PAD dan rendahnya kontribusi pajak dan retribusi daerah terhadap PAD. Hal ini mendukung pendapat Mahmudi (2010:143) bahwa semakin tinggi Rasio Efektifitas PAD maka semakin besar tingkat efektifitas pemerintah kabupaten dalam memperoleh PAD.

Pada penelitian yang dilakukan oleh Kalalo, et al (2014) Kinerja Keuangan pada Pemerintah Kota Manado menunjukkan Rasio Efektifitas PAD pemerintah daerah dalam memobilitas penerimaan PAD belum sesuai dengan yang ditargetkan. Penyebab terjadinya hal tersebut hampir sama apa yang dijelaskan pada penelitian ini dimana kedua daerah ini yaitu Kota Manado dan Kabupaten Morowali belum mampu memobilitas PAD agar sesuai dengan yang ditargetkan. Kedua daerah tersebut diharapkan dapat memaksimalkan potensi PAD yang ada, sehingga mampu mencapai target pendapatan yang telah ditetapkan sebelumnya. Namun perbedaannya, efektifitas PAD Kota Manado dapat dikatakan efektif karena setiap tahunnya mengalami peningkatan. 


\section{Gramini M.}

\section{Analisis Kinerja Belanja Daerah}

\section{Analisis Varians Belanja Daerah}

Analisis ini menunjukkan bahwa Kabupaten Morowali memiliki kinerja belanja yang baik. Selisih anggaran yang terendah terjadi pada tahun 2013 yang disebabkan karena besarnya belanja pegawai yang dikeluarkan pemerintah Kabupaten Marowali. Sama halnya selisih positif yang terjadi pada tahun-tahun lainnya disebabkan oleh belanja pegawai, hanya saja yang membedakannya adalah besar kecilnya belanja pegawai yang dikeuarkan oleh pemerintah Kabupaten Morowali. Hasil ini juga mendukung pendapat yang dikemukakan oleh Mahmudi (2010:157) yaitu pemerintah daerah dikatakan memiliki kinerja belanja yang baik apabila realisasi belanja tidak melebihi dari yang ditargetkan.

Pada penelitian yang dilakukan oleh Saputra. et.al (2016) kinerja keuangan daerah Kabupaten Jembrana menunjukkan analisis varians belanja daerah secara keseluruhan termasuk dalam ketegori baik karena memiliki nilai selisih positif yang berarti pemerintah daerah mengunakan anggaran belanja tidak melebihi yang ditargetkan pada tahun 2010-2014. Hal tersebut sama dengan penelitian ini, menunjukkan analisis varians belanja daerah secara keseluruhan termasuk dalam ketegori baik yang berarti pemerintah daerah mampu menggunakan anggaran belanja agar tidak melebihi anggaran.

\section{Analisis Keserasian Belanja Daerah}

Analisis keserasian belanja daerah secara umum terlihat bahwa sebagian besar dana belanja daerah dialokasikan untuk Belanja Operasi dan hanya beberapa persen dialokasikan untuk Belanja Modal. Proporsi belanja daerah selama tahun 2011-2015 untuk menunjukkan bahwa belanja operasi mengalami keserasian belanja dengan rata-rata sebesar 75,42\%, sedangkan untuk Belanja Modal kurang serasi dengan rata-rata sebesar 24,43\%. Hasil ini mendukung pendapat Mahmudi (2010:164) bahwa pemerintah dengan tingkat pendapatan tinggi cenderung memiliki porsi Belanja Operasi yang tinggi dibandingkan pemerintah daerah yang tingkat pendapatan rendah. Besarnya alokasi dana untuk belanja operasi terutama dikarenakan besarnya dinas-dinas otonomi dan belanja pegawai.

Pada penelitian yang dilakukan oleh Puput Risky P (2015) di Kabupaten Kebumen menunjukkan alokasi Belanja Operasinya lebih besar dibandingkan dengan Belanja Modalnya. Hal tersebut sama dengan penelitian ini, alokasi Belanja Operasi Kabupaten Morowali juga lebih tinggi dibandingkan dengan Belanja Modalnya. Besarnya alokasi dana untuk belanja operasi terutama dikarenakan besarnya dinas-dinas otonomi dan belanja pegawai untuk gaji PNS.

\section{Analisis Efisiensi Belanja Daerah}

Efesiensi belanja daerah jika dilihat dari nominalnya memiliki nilai yang berfluktuasi dari tahun ke tahun, namun dilihat dari rasionya secara keseluruhan tetap berada dibawah $100 \%$. Analisis ini menunjukkan bahwa Kabupaten Morowali telah melakukan efisiensi belanja pada 2011-2015 dengan rata-rata 89,43\% berarti realisasi belanja Kabupaten Morowali yang tidak melebihi anggaran belanja. Hasil ini mendukung pendapat Mahmudi (2010:166) jika angka yang dihasilkan kurang dari 100\% maka dinilai telah melakukan efisiensi anggaran.

Pada penelitian Saputra. et.al (2016) di Kabupaten Jembrana menunjukkan rasio efisiensi belanja daerah secara keseluruhan termasuk dalam ketegori efisien karena memiliki nilai dibawah 100\% yang berarti tidak terjadi pemborosan anggaran pada tahun 2010-2014. Hal tersebut sama dengan penelitian ini yang menunjukkan kinerja belanja daerah Kabupaten Morowali telah melakukan efisiensi anggaran belanja atau tidak ada pemborosan dalam penggunaan anggaran belanja pada tahun 2011-2015. Dalam hal ini, Kabupaten Morowali perlu lebih jeli lagi dalam menggunakan anggaran belanja agar lebih memprioritaskan belanjanya untuk kegiatan yang mampu menopang pelaksanaan desentralisasi. 


\section{KESIMPULAN DAN SARAN}

\section{Kesimpulan}

\section{a. Analisis Kinerja Pendapatan Daerah}

1. Berdasarkan hasil analisis Varians Pendapatan Daerah tahun 2011-2015 menunjukkan bahwa Kabupaten Morowali termasuk dalam kategori kurang baik karena secara keseluruhan memiliki selisih negatif berarti daerah belum mampu mencapai target pendapatan yang ditetapkan.

2. Berdasarkan hasil analisis rata-rata Derajat Desentralisasi tahun 2011-2015 adalah 5,14\% dapat dikatakan sangat kurang yang berarti bahwa rendahnya konribusi PAD terhadap pendapatan daerah. Rata-rata Kemandirian keuangan daerah tahun 2011-2015 adalah 5,52\% termasuk dalam kategori rendah sekali dengan pola hubungan instruktif yang berarti peranan pemerintah pusat masih dominan dalam pelaksanaan desentalisasi. Rata-rata Ketergantungan keuangan tahun 2011-2015 sebesar 93,86\% termasuk dalam kategori sangat tinggi yang berarti bahwa daerah masih tergantung kepada pemerintah pusat. Rata-rata tingkat efektifitas PAD sebesar 69,35\% sehingga dikatakan tidak efektif yang berarti bahwa daerah belum efektif dalam memobilisasi penerimaan PAD.

\section{b. Analisis Kinerja Belanja Daerah}

1. Berdasarkan hasil analisis varians belanja daerah Kabupaten Morowali selama tahun 2011-2015 menunjukkan bahwa kinerja belanja daerah termasuk dalam kategori baik karena secara keseluruhan memiliki selisih positif yang berarti tidak terjadi pemborosan anggaran.

2. Berdasarkan hasil analisis keserasian belanja Kabupaten Morowali secara umum menunjukkan bahwa sebagian besar belanja daerah dialokasikan untuk Belanja Operasi dan hanya beberapa persen dialokasikan untuk Belanja Modal. Selama tahun 2011-2015 rata-rata Belanja Operasi sebesar 75,42\% berarti serasi sedangkan Belanja Modal sebesar 24,43\% berarti kurang serasi.

3. Kinerja Belanja Kabupaten Morowali dilihat dari efisiensi belanja daerah secara keseluruhan termasuk dalam ketegori efisien karena memiliki nilai dibawah $100 \%$ yaitu 89,43\% yang berarti bahwa daerah mampu mengendalikan penggunaan anggaran.

\section{Saran}

1. Bagi Pemerintah Kabupaten Morowali

a. Kabupaten Morowali perlu meningkatkan Pendapatan Asli Daerah dengan cara meningkatkan efisiensi untuk beberapa pos yang berhubungan dengan PAD Kabupaten Morowali. Efisiensi akan meningkat jika Pemerintah Kabupaten Morowali dapat melaksanakan secara lebih optimal pemungutan pajak dan retribusi daerah yang masih memiliki kontribusi kecil dalam PAD. Ada juga dengan cara melakukan pengawasan dan pengendalian secara benar dan berkelanjutan untuk menghindari terjadinya penyimpangan dalam pemerolehan PAD oleh yang bersangkutan.

b. Tingkat kemandirian keuangan daerah yang rendah sekali dengan pola hubungan instruktif juga merupakan masalah dalam Pemerintahan Kabupaten Morowali, maka dari itu Pemerintah Kabupaten Morowali perlu menggali lebih lagi guna mencari beberapa potensi dari masyarakat maupun alam untuk meningkatkan PAD Kabupaten Morowali.

2. Bagi peneliti selanjutnya

a. Periode penelitian ini terbatas untuk tahun 2011-2015. Diharapkan penelitian selanjutnya menambahkan periode tahun penelitian agar lebih akurat.

b. Peneliti selanjutnya disarankan memperluas lingkup wilayah penelitian. karena penelitian ini mengambil satu kabupaten di provinsi Sulawesi Tengah yaitu Kabupaten Morowali. 
Gramini M.

\section{REFERENSI}

Assidiqi, Bahrun. 2014. Analisis Kinerja Keuangan Anggaran Pendapatan Dan Belanja Daerah Kabupaten Klaten Tahun 2008-2012. Skripsi. Fakultas Ekonomi Universitas Negeri Yogyakarta.

Bastian, Indra. 2006. Akuntansi Sektor Publik: Suatu Pengantar. Erlangga, Jakarta.

Batafor, Gregorius Gehi. 2011. Evaluasi Kinerja Keuangan Dan Tingkat Kesejahteraan Masyarakat Kabupaten Lembata - Provinsi NTT. Tesis. Program Magister, Program Studi Manajemen Universitas Udayana. Denpasar

Bisma, I Dewa Gde dan Hery Susanto 2010. Evaluasi Kinerja Keuangan Daerah Pemerintah Provinsi Nusa Tenggara Barat Tahun Anggaran 2003-2007. Ganec Swara Edisi Khusus (Vol. 4 No.3. Desember 2010).

Dinas Pendapatan, Pengelolaan Keuangan dan Aset Daerah. 2016. Realisasi Anggaran Pendapatan dan Belanja Daerah periode 2011-2015. Dinas Pendapatan. Pengelolaan Keuangan dan Aset Daerah Kabupaten Morowali, Sulawesi Tengah.

Halim, Abdul. 2002. Manajemen Keuangan Daerah. Bunga Rumpai. UPP STIM YKPN, Yogyakarta.

Kalalo, Nadya Pretti., Jantje J. Tinangon dan Inggriani Elim. 2014. Pengukuran Kinerja Keuangan Pada Pemerintah Kota Manado. Jurnal EMBA. ISSN 2303-1174. Vol.2 No.1 Hal. 606-616.

Mahmudi. 2010. Analisis Laporan Keuangan Pemerintah Daerah. Edisi Dua. UPP STIM YKPN. Yogyakarta.

Paramita, Puput Risky. 2015. Analisis Rasio Untuk Menilai Kinerja Keuangan Daerah Kabupaten Kebumen Tahun 2009-2013. Skripsi. Fakultas Ekonomi Universitas Negeri Yogyakarta.

Santosa, Pandji. 2008. Administrasi Publik: Teori dan Aplikasi Good Governance. PT. Refika Aditama, Bandung.

Saputra, Sandy Candra.. I Wayan Suwendra dan Fridayana Yudiaatmaja. 2016. Analisis Kinerja Keuangan Pemerintah Daerah Dalam Pengelolaan Anggaran Pendapatan Dan Belanja Daerah di Kabupaten Jembrana tahun 2010 - 2014. e-Journal Bisma Universitas Pendidikan Ganesha. Jurusan Manajemen (Volume 4 Tahun 2016).

Undang-Undang Republik Indonesia Nomor 32 Tahun 2004 Tentang Pemerintah Daerah.

Yani, Ahmad. 2008. Hubungan Keuangan antara Pemerintah Pusat dan Daerah di Indonesia. Edisi Revisi-3. PT. Raja Grafindo Persada, Jakarta. 